Journal

of Geography,

Politics and Society

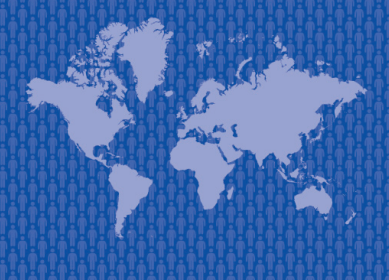

$7(4) / 2017$

\section{Journal of Geography, Politics and Society}

$2017,7(4), 53-56$

DOI 10.4467/24512249JG.17.038.7638

\title{
UNWTO SUSTAINABLE TOURISM OBSERVATORY IN UKRAINE: NATIONAL PRIORITIES
}

\author{
Kostyantin Babov (1), Tetyana Bezverkhniuk (2), Iryna Babova (3), Ivan Liptuga (4)
}

(1) SI “Ukrainian Research Institute of Medical Rehabilitation and Resort Therapy of Ministry of Health of Ukraine”, Lermontovsky lane 6, 65014, Odessa, Ukraine, e-mail:mrik@kurort.odessa.net

(2) Odessa Regional Institute of Public Administration of National Academy of Public Administration under the President of Ukraine, Genuezka 22, 65009, Odessa, Ukraine,

e-mail: tatiana.bezverkhniuk@gmail.com (corresponding author)

(3) SI “Ukrainian Research Institute of Medical Rehabilitation and Resort Therapy of Ministry of Health of Ukraine", Lermontovsky lane 6, 65014, Odessa, Ukraine, e-mail: babovairina@gmail.com

(4) Advisor to the First Vice Primeminister-Minister of Economic Development and Trade, Ministry of Economic Development and Trade of Ukraine, Hrushevskoho 12/2, 01008, Kiev, Ukraine,

e-mail: iptuga@gmail.com

\section{Citation}

Babov K., Bezverkhniuk T., Babova I., Liptuga I., 2017, UNWTO sustainable tourism observatory in Ukraine: natural priorities, Journal of Geography, Politics and Society, 7(4), 53-56.

\begin{abstract}
The article focuses on working out sustainable tourism indicators taking into account national priorities of Ukraine. Among national priorities of tourism in Ukraine the varied and diverse natural healing resources (mineral waters, peloids (medical mud), climate, rump of estuaries and lakes, seawater, ozocerite, bischofite) and resort territories are the leading ones. Assessment of the state of natural healing resources and resort territories is suggested as a national priority among nine mandatory problem areas according to UNWTO recommendations for monitoring in observatories of sustainable tourism.
\end{abstract}

\section{Key words}

sustainable tourism observatory, national priorities, Ukraine, resorts, natural healing resources, indicators.

Received: 12 August 2017 Accepted: 29 September 2017

Published: 29 December 2017

\section{Introduction}

In the last six decades, tourism has been undergoing expansion and diversification processes, becoming one of the fastest growing sectors of the world economy. The rapid growth of the tourist sector is a problem in terms of irrational use of resources, degradation of natural and cultural heritage, as well as negative social consequences. This grounds the need to change the paradigm of the development of tourism in the direction of rational and responsible use of recreational and tourist resources in accordance with the principles of sustainable development.

It is tourism that combines all three components of sustainable development (economic, social and environmental), contributing to the preservation 
and protection of the environment, economic growth and social well-being. The beginning of the implementation of the principles of sustainable development in the tourism sector dates back to 1980-1990 (Butler, 1999), but these attempts were unsystematic and sporadic (Ткаченко, 2009).

Taking into account the resolution of the XXI session of the General Assembly of the World Tourism Organization (UNWTO) in 2015 «International Year of Sustainable Tourism for Development in 2017», the United Nations (UN) decided to proclaim 2017 as the International Year of Sustainable Tourism for Development (Resolution adopted by the General Assembly of United Nations 2015). The Decree of President of Ukraine dated January 12, 2015, No. 5/2015, approved the Strategy of Sustainable Development of Ukraine 2020 in which tourism is in the list of priority programs (Указ Президента України..., 2015). The Resolution of the Cabinet of Ministers of Ukraine dated 16 March 2017 No. 168-r approved the Strategy for the Development of Tourism and Resorts for the period up to 2026, which emphasized the need to adhere to the principles of sustainable tourism development (Розпорядження Кабінету Міністрів України..., 2017).

The UN General Assembly in 2015 adopted a Sustainable Development Program until 2030 and set 17 Sustainable Development Goals aimed at combating poverty, protecting the environment and improving the quality of life of mankind (Transforming..., 2015):

1. End poverty in all its forms everywhere.

2. End hunger, achieve food security and improved nutrition and promote sustainable agriculture.

3. Ensure healthy lives and promote well-being for all at all ages.

4. Ensure inclusive and equitable quality education and promote lifelong learning opportunities for all.

5. Achieve gender equality and empower all women and girls.

6. Ensure availability and sustainable management of water and sanitation for all.

7. Ensure access to affordable, reliable, sustainable and modern energy for all.

8. Promote sustained, inclusive and sustainable economic growth, full and productive employment and decent work for all.

9. Build resilient infrastructure, promote inclusive and sustainable industrialization and foster innovation.

10. Reduce inequality within and among countries.

11. Make cities and human settlements inclusive, safe, resilient and sustainable.
12. Ensure sustainable consumption and production patterns.

13. Take urgent action to combat climate change and its impacts.

14. Conserve and sustainable use the oceans, seas and marine resources for sustainable development.

15. Protect, restore and promote sustainable use of terrestrial ecosystems, sustainable manage forests, combat desertification, and halt and reverse land degradation and halt biodiversity loss.

16. Promote peaceful and inclusive societies for sustainable development, provide access to justice for all and build effective, accountable and inclusive institutions at all levels.

17. Strengthen the means of implementation and revitalize the Global Partnership for Sustainable Development.

UN and UNWTO highlight the priority of tourism in the implementation of goals 8, 12 and 14 (Tourism..., 2015), although it is fully certain that tourism plays a leading role in addressing all sustainable development goals. UNWTO's initiative to realize the global goals of sustainable development was the establishment in 2004 of the International Network of Sustainable Tourism Observatories (INSTO), which monitors the economic, environmental and social impact of tourism at the level of the Destinations (UNWTO, International Network of Sustainable Tourism Observatories). There are currently 20 observatories in the world: 8 in China, 1 in Greece, 1 in Mexico, 1 in Brazil, 5 in Indonesia, 1 in Croatia, 2 in the USA and 1 in New Zealand. The objectives of the observatories of sustainable tourism development are:

1. Integrated Approach to provide a framework for the systematic, timely and regular monitoring of resource-use and a better understanding of the impact of tourism.

2. Evidence to establish a strong foundation of tangible and structured data for well-informed decision making.

3. Stakeholder Empowerment to actively engage local stakeholders in the measurement of risks, costs, impacts, limits and opportunities through an inclusive and participatory approach.

4. Network and Learn to exchange information for improved knowledge, collaboration, communication and greater public accountability.

5. Performance Measurement to monitor and advise on the implementation of sustainable development plans, policies and management actions.

6. Continuity to foster long-term commitment for regular monitoring. 
Various indicators have been developed in the tourism sector for measuring and managing tourism development (Practical..., 2017; Indicators..., 2004) in the past decades. The possibility of a correct comparison of results between destinations is the most often motive and the main purpose of these initiatives (Torres-Delgado, Saarinen, 2014).

According to UNWTO recommendations for monitoring observatories of sustainable tourism, nine mandatory problem areas need to be assessed: tourism seasonality, employment, destination economic benefits, governance, local satisfaction, energy management, water management, waste water (sewage) management, solid waste management (International..., /no data/; Measuring..., 2017). However, each destination is a complex ecosystem with its own individual characteristics, which necessitates the development of indicators taking into account national priorities.

\section{Analysis of national priorities of Ukraine in UNWTO Sustainable Tourism Observatory}

We consider that monitoring of the status of resort tourist destinations and recreational resources is Ukraine's National Priority for the Sustainable Tourism Observatory. In Ukraine are concentrated $47 \%$ of all healing mineral resources of Europe, which are located almost in all the regions of the country forming an incomparable tourist potential. According to the Law of Ukraine "On Resorts" healing mineral resources are mineral waters, peloids (medical mud), climate, rump of estuaries and lakes, seawater, ozocerite, bischofite (Закон України..., 2000).

The resort complex of Ukraine is a large socially oriented industry of health and recreation, the main component of which are the largest reserves of recreational and healing mineral resources in Europe. It is a healing climate and recreational areas, mineral waters and peloids (medical mud) of all balneological types due to the countryss good geographical location, modern hydrosphere dynamics, geological structure, represented by the ancient tectonic form - the Ukrainian crystalline massif, huge hollows of several kilometres and active mountain formations. Almost all types of underground and surface mineral waters are found in Ukraine, both for internal and external uses, among them there are such rare waters as the ones with specific organic substances («Naftusya», Truskavets resort, Lviv region), organic substances and metasilic acid (Berezovsky mineral waters, Kharkiv region); carbonic, ferruginous, arsenic, sulphide, radon, thermal waters, etc.; Sulphide, peat, sapropel, soponic peloids (medical mud), bischofite and ozocerite (Бабов et al. (eds.), 2009).

Only in Ukraine there are estuary complexes of the north-western Black Sea and Azov region, the deposits of thermal (Zakarpattia, Kherson, Odessa region) and radon (Vinnytsia region) mineral waters, ozokerite (Lviv region), bishofit (Poltava region), unique therapeutic climatic conditions, in particular Solotvin salt caves (Transcarpathian region), etc., which allows creating unique climatic, balneological, mud resorts. Significant are deposits of amber, which in other countries (Poland, Lithuania, Czech Republic, Russia, Japan) is successfully used in the resort and tourist sector.

Today the only institution that carries out fundamental researches of natural healing resources of Ukraine, forms strategy of resort area development and provides sustainable development of tourism and resorts in Ukraine, is the State Institution "Research Institute of Medical Rehabilitation and Resorts of the Ministry of Health of Ukraine" (Institute). It has been a number one scientific task of the Institute during 90 years of its work.

The main directions of the Institutess activities are systematic scientific studies of the state of recreational territories, natural healing resources, working out of complex programs for the resort areas development and sustainable tourism in Ukraine. In particular, expert-analytical support for conferring the status of state or local resorts (due to presence of unique natural healing resources in resort territory state resorts, or common ones - local resort) to recreational resort territories (Бабов, Нікіпелова (eds.), 2010), monitoring the State Cadastre of natural healing resources (Бабов et al. (eds.), 2017), medical and biological evaluation of natural healing resources (mineral waters, medical mud, climatic conditions, etc.) and their monitoring. The Institute has provided more than 500 medical balneological conclusions on mineral waters, medical mud (peloids), ozocerite, bischofite, which is the basis for their therapeutic usage and industrial packaging.

With regard to the requirements of the Law of Ukraine «On Resorts» on the basis the Institute's scientific researches as the state resorts were declared resort Khmelnik (Vinnitsa region), Berdyansk (Zaporozhye region), Saky (Crimea), Skadovsk (Kherson region), Mirgorod (Poltava region), Slavyansk (Donetsk region); as the local resorts - Solotvyno (Transcarpathian region) and Kosiv (Ivano-Frankivsk region). The Institute identified prospective territories for the development as resort tourist destinations, in particular, in the Lviv region (Skhidnytsia, Truskavets, Morshyn - state resorts, Nemirov, Lubin Velikiyt - local resorts), Volyn region (Shatsk - state resort), 
Odessa region (Kuyalnik - state resort, Sergievka, Zatoka - local resorts), Mykolaiv region (Koblevoe local resort), Kharkiv region (Lyubotin - local resort), Khmelnitsky region (Sataniv, Kamyanets-Podilskyi local resorts), Kyiv region (Vorzel - local resort), etc. Resort and touristic orientation has a town-creating potential for the mentioned resort territories as well as increases their investment potential and attractiveness (lжa et al. (eds.), 2016).

\section{Conclusions}

The creation of a Sustainable Tourism Observatory in "Research Institute of Medical Rehabilitation and Resorts of the Ministry of Health of Ukraine" fully meets the goals of sustainable development established by the United Nations and the activities of the World Tourism Organization (UNWTO) to create a worldwide international network of sustainable tourism observatories (INSTO). The initiative was supported by the Department of Tourism and Resorts of Ministry of Economic Development and Trade of Ukraine, National Tourism Organization with the Institute being the basis for the implementation of the Strategy for the Development of Tourism and Resorts in Ukraine taking into account the principles of sustainable tourism development.

Diversity of natural healing resources and resort areas in Ukraine determine the priority of their assessment in the development of the sustainable tourism indicators for the Sustainable Tourism Observatory. The implementation of the principles of sustainable tourism development in resort and tourist regions will promote their environmental safety and proper protection of the natural resources, increase of economic indicators, investment attractiveness and social well-being (creation of new year-round workplaces, improvement of transport infrastructure of the region, etc.).

\section{References}

Butler R., 1999, Sustainable tourism: a state-of-the-art review, Tourism Geographies, 1(1), 7-25.

Indicators of Sustainable Development for Tourism Destinations: A Guidebook, 2004, UNWTO, Madrid.

International Network of Sustainable Tourism Observatories (INSTO), /no data/, The World Tourism Organization (UNWTO), http://insto.unwto.org/ [29.07.2017].

Measuring Sustainable Tourism: A call for Action - Report of the 6th International Conference on Tourism Statistics, Manila, Philippines, 21 - 23 June 2017, 2017, UNWTO, Madrid.

Practical Guidelines for Integrated Quality Management in Tourism Destinations - Concepts, Implementation and Tools for Destination Management Organizations, 2017, World Tourism Organization, Madrid.

Resolution adopted by the General Assembly of United Nations on 22 December 2015 [on the report of the Second Committee (A/70/472)] 70/193. International Year of Sustainable Tourism for Development, 2017.

Torres-Delgado A., Saarinen J., 2014, Using indicators to assess sustainable tourism development: a review, Tourism Geographies, 16(1), 31-47.

Tourism and the Sustainable Development Goals, 2015, World Tourism Organization (UNWTO), Madrid.

Transforming our world: the 2030 agenda for sustainable development, 2015, United Nations, https://sustainabledevelopment.un.org A/RES/70/1 [23.07.2017].

Бабов К.Д., Єжов В.В., Торохтін О.М. (eds.), 2009, Курорти та санаторії України: Науково-практичний довідник, Фолігрант, Київ.

Бабов К.Д., Нікіпелова О.М. (eds.), 2010, Курорти України державного та місцевого значення, ПАЛЬМІРА, Одеса.

Бабов К.Д., Нікіпелова О.М., Мокієнко А.В. (eds.), 2017, Державний кадастр природних лікувальних ресурсів. Здобутки і перспективи, Фенікс, Одеса.

Закон України № 2026-ІІІ від 05.10.2000 р. «Про курорти», 2000, Відомості Верховної Ради України, 2000, № 50, стаття 435.

Іжа М.М., Бабов К.Д., Безверхнюк Т.М. (eds.), 2016, Регіональний туристичний продукт: проектний підхід до забезпечення конкурентоспроможності, ОРІДУ НАДУ, Одеса.

Розпорядження Кабінету Міністрів України № 168-р від 16.03.2017 р. «Про схвалення Стратегії розвитку туризму та курортів на період до 2026 року», 2017, Офіційний вісник України, 2017, № 26.

Ткаченко Т.І., 2009, Сталий розвиток туризму: теорія, методологія, реалії бізнесу, Київський національний торговельно-економічний університет, Київ.

Указ Президента України № 5/2015 від 12.01.2015 р. «Про Стратегію сталого розвитку «Україна - 2020», 2015, Урядовий кур'єр, № 6. 